\title{
Evaluation of Adult Abdominal Trauma Patients and Intra Abdominal Solid Organ Injuries
}

Erişkin Karın Travma Hastalarının ve Karın İçi Solid Organ Yaralanmalarının Değerlendirilmesi

Erol ACAR ${ }^{1}$, (D) Seda ÖZKAN², iD Selim GENÇ ${ }^{3}$, Süleyman ALTUN ${ }^{3}$

1- Kırıkkale Yüksek İhtisas Hastanesi Acil Tıp Kliniği, Kırıkale, Türkiye, 2- IÜC, Cerrahpaşa Tıp Fakültesi, Acil Tıp Anabilim Dalı, İstanbul, Türkiye, 3- Ankara Dışkapı Yıldırım Beyazıt Eğitim ve Araştırma Hastanesi, Acil Tıp Kliniği, Ankara, Türkiye.

\begin{abstract}
Objectives: In our study, adult patients who underwent abdominal trauma in the emergency department and received abdominal tomography; We aimed to examine demographic features, clinical and laboratory findings of abdominal trauma, severity of trauma, mortality rates, intra-abdominal solid organ injury rates, and degree of injury to organs and contribute to the literature.

Methods: This study was carried out as a result of retrospective examination of 335 patients over the age of 18 who underwent tomography, considering abdominal injury from multiple trauma patients admitted to the emergency department. Age, gender, mechanism of injury, accompanying system injuries, vital signs, physical examination findings, laboratory values, solid organ injury degree, injury severity scores, treatments, and final status of the cases were recorded. The data obtained were analyzed statistically.

Results: $76.2 \%$ of the cases were male and the mean age of the patients was $41 \pm 18.4$ years. Blunt injury was detected in $92.8 \%$ and penetrating injury in $7.2 \%$ of patients with suspected abdominal injury. The mortality rate of all patients was $1.2 \% .12 .8 \%$ of the patients had solid organ injuries. $95.3 \%$ of patients with solid organ injuries were blunt injuries. Liver injury was detected in $55.8 \%$, spleen injury in $41.9 \%$ and kidney injury in $18.6 \%$ of cases with solid organ injury. While $79.1 \%$ of patients with solid organ injuries were treated conservatively, $20.9 \%$ were treated surgically. Injury severity scores and transaminase values of patients with solid organ injuries were significantly higher $(p<0.05)$.

Conclusion: As a result; multiple intra-abdominal organ injuries, accompanying extra-abdominal injuries, degree of injury of the affected solid organ, high trauma index are among the factors affecting mortality and morbidity in abdominal injuries.

ÖZET

Amaç: Çalışmamızda acil serviste karın yaralanması düsünülüp batın tomografisi çekilen erişkin olguların: demografik özelliklerini, karın yaralanmalarının klinik ve laboratuar bulgularını, travmanın şiddetini, mortalite oranlarını, karın içi solid organ yaralanma oranlarını ve organların yaralanma derecelerini incelemeyi ve literatüre katkıda bulunmayı amaçladık.

Yöntem: Bu çalıșma acil servise gelen çoklu travma hastalarından batın yaralanması düșünülüp tomografi çekilen 18 yaş üzerindeki 335 hastanin geriye dönük incelenmesi sonucu gerçekleştirildi. Olguların yaşl, cinsiyeti, yaralanma mekanizmast, eşlik eden diğer sistem yaralanmaları, vital bulguları, fizik muayene bulguları, laboratuar değerleri, solid organ yaralanma derecesi, olguları yaralanma şiddet skorları, tedavileri ve son durumları kaydedildi. Elde edilen veriler istatistiksel olarak incelendi.

Bulgular: Olguları \% 76.2 erkekti ve hastaların yaş ortalaması $41 \pm 18.4$ idi. Batın yaralanması şüphesi olan hastalarn $\% 92.8$ 'inde künt yaralanma ve \%7.2'sinde ise penetran yaralanma tespit edildi. Tüm hastalartn mortalite oranı \%1.2 tespit edildi. Hastaların \% 12.8 'inde solid organ yaralanması mevcuttu. Solid organ yaralanması olan hastaların \%95.3'ü künt yaralanma idi. Solid organ yaralanması olan olguların \%55.8'inde karaciğer, \%41.9'sinda dalak, \%18.6'sinda böbrek yaralanması tespit edildi. Solid organ yaralanmast tespit edilen hastalarn \%79.1'i konservatif tedavi edilirken \%20.9'una cerrahi tedavi uygulandl. Solid organ yaralanmast olan hastaların yaralanma șiddet skorları (ISS ve NISS) ve transaminaz değerleri anlamlı derecede yüksek bulundu $(p<0.05)$.

Sonuç: Sonuç olarak; karın travma olgularında birden fazla karın içi organın yaralanması, eșlik eden karın dışı yaralanmalar, etkilenen solid organın yaralanma derecesi, yüksek travma indeksi mortalite ve morbiditeyi etkileyen faktörler arasinda yer almaktadır.
\end{abstract}

\section{GíRiş}

Karın yaralanmaları; baș-boyun ve toraks yaralanmalarından sonra travmaya bağglı üçüncü en sık ölüm nedenidir. Tüm travmaya bağlı ölümlerin \%1520'si karın yaralanmalarına bağlıdır (1-3). Karın travmaları kafa ve göğüs travmalarından daha az ölümcül olmalarına rağmen, kendisine bağlı ölümlerin erken tanı ve tedavisi yapıldığında en yüksek oranda önlenebilir travma grubu olması nedeni ile önemini korumaktadır. Karın travmasında erken ölümler genellikle masif hemorajiye bağlıdır. Geç dönemde ise enfeksiyon ve sepsise bağlı mortalite ve morbidite görülür (1-3).

Karın yaralanmaları künt ve penetran travmalardan oluşurlar. Künt karın yaralanmaları genellikle motorlu araç kazaları, darp, iş kazaları veya düşmeler sonucu

Received: 25.04 .2020

Accepted: 11.05 .2020

Correspondence: Seda ÖZKAN, İstanbul Üniversitesi-Cerrahpaşa, Cerrahpaşa Tıp Fakültesi, Acil Tıp Anabilim Dalı, İstanbul, Türkiye E mail: sedacil@gmail.com_Tel: 00905321664488

Cite this article as: Acar E, Özkan S, Genç S, Altun S. Evaluation of Adult Abdominal Trauma Patients and Intra Abdominal Solid Organ Injuries. Phnx Med J. 2020;2(1):90-97. 
meydana gelmektedir (1-3). Künt karın yaralanmaları genellikle çoklu yaralanmalı hastalarda ortaya çıkarlar. $\mathrm{Bu}$ nedenle erken tanı ve tedavi önceliklerinin belirlenmesi penetran yaralanmalara kıyasla geç olabilmektedir. Künt karın yaralanmasında en sık yaralanan solid organ dalak ve karaciğerdir (4).

Penetran yaralanmalar ise ateşli silah ve delici kesici alet yaralanmaları ile oluşur. Karın içi organ yaralanma ihtimali ateşli silah yaralanmalarında \%90-98 iken delici kesici alet yaralanmalarında \%55-60 arasındadır. Penetran yaralanmalarda solid organ yaralanmalarının yanısıra künt yaralanmalara kıyasla içi boş organ yaralanmaları daha sık gözlenmektedir (1-4).

Biz çalışmamızda acil serviste karın yaralanması düşünülüp batın tomografisi çekilen erişkin olguların; demografik özelliklerini, karın yaralanmalarının klinik ve laboratuar bulgularını, travmanın şiddetini, mortalite oranlarını, karın içi solid organ yaralanma oranlarını ve organların yaralanma derecelerini incelemeyi ve literatüre katkıda bulunmayı amaçladık.

\section{GEREÇ VE YÖNTEM}

$\mathrm{Bu}$ çalışma 2012 yılı Ocak -Aralık tarihleri arasında acil servise gelen çoklu travma hastalarından karın yaralanması düşünülüp tomografi çekilen 18 yaş üzerindeki 335 hastanın geriye dönük incelenmesi sonucu gerçekleştirildi. Çalışmanın etik kurul onayı (26 Ocak 2015 tarihli ve 19/01 onay numarali) Ankara Dışkapı Yıldırım Beyazıt Eğitim ve Araştırma Hastanesi klinik araştırmalar etik kurulundan alındı. On sekiz yaşın altındaki çocuklar çalışma dışı bırakıldı. Olguların yaşı, cinsiyeti, travmanın oluş şekli (künt, penetran), yaralanma mekanizması (araç içi trafik kazası, araç dışı trafik kazası, delici-kesici alet yaralanması, ateşli silah yaralanması, yüksekten düşme, düz zeminde düşme, darp, diğer), eşlik eden diğer sistem yaralanmaları, başvuruda olan vital bulgular, başvuru anındaki fizik muayene bulguları, tam kan sayımı (beyaz küre sayısı, hemoglobin ve hematokrit düzeyi), biyokimyasal testler (Aspartat amino transferaz (AST), Alaninaminotransferaz (ALT), kan üre nitrojeni, kreatinin vb.), solid organ yaralanma derecesi, olguların Glasgow koma skoru (GKS), yaralanma şiddet skoru (ISS) ve yeni yaralanma şiddet skoru (NISS) tedavi şekli (cerrahi, konservatif) ve son durumu (şifa, ölüm) dosyalarından tarandı. Elde edilen veriler oluşturulan çalışma formuna işlendi.

Hastaların dosyalarından elde edilen veriler SPSS 17.0 (Statistical Package for Social Science) bilgisayar programına yüklendi. Verilerin normallik analizi Kolmogorov Smirnov testi kullanılarak yapıld1, grupların normal dağılıma uymadığı belirlendi. Çalışma verileri değerlendirilirken sürekli değişkenler ortalama \pm standart sapma olarak verildi. Gruplar arasındaki ikili karşılaştırmalarda Mann-Whitney U testi uygulandı. Anlamlılık düzeyi $\mathrm{p}<0.05$ olarak kabul edildi. İkili grup karşılaştırılmasında ise frekans veriler için ki-kare testi uygulandı. İkili grupların ordinal verileri içinse Mann-Whitney U testi uygulandı.

\section{BULGULAR}

Çalışmayı yaptığımız süre boyunca karın yaralanması şüphesi olan ve batın tomografisi çekilen hasta sayısı 335 idi. Olguların \%76.2 $(\mathrm{n}=256)$ si erkek, \%23.8 $(\mathrm{n}=80)$ kadın idi. Hastaların yaş ortalaması $41 \pm 18.4$ (18-88) idi. Olguların \%99.4 $(\mathrm{n}=334)$ ambulans ile ve olay olduktan ilk bir saat içinde acil servisimize başvurdu. İki olgu ise bir saatin üzerinde bir süre içinde acil servise başvurmuştu.

Karın yaralanması şüphesi olan hastaların \%92.8'inde künt yaralanma ve \%7.2'sinde ise penetran yaralanma tespit edildi. Penetran yaralanmaların da \%4.8'ini delici kesici alet yaralanması, \%2.4'ünü ateşli silah yaralanması oluşturmaktaydı. Künt yaralanmalarda \%73.5 ( $\mathrm{n}=247)$ ile araç içi trafik kazası (AİTK) ilk sırada yer almaktaydı (Tablo 1). Karın harici yaralanan bölgelerine bakıldığında; en çok \%49.4 ile $(n=166)$ baş-boyun yaralanmasının olduğu görüldü (Tablo 1). Olguların karın yaralanması düşündürecek semptom ve bulguları tablo 1'de gösterildi.

Batın tomografisi çekilen hastaların \% 12.8'inde solid organ yaralanması mevcuttu (Tablo 1). Olguların 4'ünde ise içi boş organ perforasyonu tespit edildi.

Acil serviste tüm hastaların \%95.8'ine sıvı ve ilaç tedavisi verilmiștir. Hastaların \%1.2'sine kan ve kan ürünleri verilmiştir. Hastaların \%2.1'ine ise mekanik ventilasyon tedavisi yapılmıştır (Tablo 1). Olguların \%65.8’i acil servisten taburcu edilirken, \%28.9'si ilgili servislere yatırılmıştır. Tüm hastaların mortalite oranı \%1.2 tespit edildi. Bir hasta ise acil serviste eks olmuştur (Tablo 1). Hastaların mortalite nedenleri ağır kafa travmasına bağlı idi.

Solid organ yaralanması olan hastaların \%95.3'ü künt yaralanma idi. Araç içi trafik kazası en fazla görülen yaralanma şekli idi (Tablo 2). Solid organ yaralanması olan olgular kendi içinde değerlendirildiğinde olguların \%55.8'inde karaciğer, \%41.9'sında dalak, \%18.6'sında böbrek yaralanması tespit edildi (Tablo 2). Solid organ yaralanması olan hastaların organ yaralanma dereceleri ise tablo 3' de gösterilmektedir.

Solid organ yaralanması tespit edilen hastaların \%79.1'i konservatif tedavi edilirken \%20.9'una cerrahi tedavi uygulanmıştır (Tablo 2). Karaciğer yaralanması olan olguların \%20.8'i cerrahiye alınırken \%79.2'si konservatif tedavi yapılmıştır. Dalak yaralanması olanların \%27.8'i cerrahi tedaviye alınırken \%72.2'si konservatif olarak tedavi edilmiştir. Böbrek yaralanması olanların ise $\% 25$ ' $\mathrm{i}$ cerrahi tedaviye alınırken \% 75'i konservatif olarak tedavi edilmiştir. 
Phnx Med J. July, 2020. Volume 2 No 2

Tablo 1: Tüm Hastaların Demografik Özellikleri

\begin{tabular}{|c|c|c|}
\hline Cinsiyet & $\mathbf{n}$ & $\%$ \\
\hline Erkek & 256 & 76.2 \\
\hline Kadın & 80 & 23.8 \\
\hline \multicolumn{3}{|l|}{ Yaralanma Mekanizması } \\
\hline Araç içi trafik kazası & 247 & 73.5 \\
\hline Araç dışı trafik kazası & 23 & 6.8 \\
\hline Delici kesici alet yaralanması & 16 & 4.8 \\
\hline Yüksekten düşme & 11 & 3.3 \\
\hline Düz zeminde düşme & 9 & 2.7 \\
\hline Ateşli silah yaralanması & 8 & 2.4 \\
\hline Darp & 6 & 1.8 \\
\hline Diğer & 11 & 3.3 \\
\hline Üzerine cisim düşmesi & 1 & 0.3 \\
\hline Eşlik Eden Diğer Sistem Yaralanmaları & $\mathbf{n}$ & $\%$ \\
\hline Baş boyun & 166 & 49.4 \\
\hline Pelvis & 84 & 25 \\
\hline Alt ekstremite & 66 & 19.6 \\
\hline Toraks & 22 & 6.5 \\
\hline Üst ekstremite & 14 & 4.2 \\
\hline Omurga & 11 & 3.3 \\
\hline Fizik Muayene Bulguları & $\mathbf{n}$ & $\%$ \\
\hline Ağr1 & 250 & 74.4 \\
\hline Hassasiyet & 230 & 68.4 \\
\hline Ekimoz & 189 & 56.3 \\
\hline Abrazyon & 116 & 34.5 \\
\hline Kesi & 16 & 4.8 \\
\hline Defans & 50 & 14.8 \\
\hline Rebound & 20 & 5.9 \\
\hline Solid Organ Yaralanması & 43 & 12.8 \\
\hline Karaciğer yaralanması & 24 & 7.2 \\
\hline Dalak yaralanması & 18 & 5.4 \\
\hline Böbrek yaralanması & 8 & 2.4 \\
\hline \multicolumn{3}{|l|}{ Acil Serviste Tedavi } \\
\hline S1v1 ve ilaç & 322 & 95.8 \\
\hline Kan ve kan ürünleri & 4 & 1.2 \\
\hline Mekanik ventilasyon & 7 & 2.1 \\
\hline \multicolumn{3}{|l|}{ Sonuç } \\
\hline Acil servisten taburcu & 221 & 65.8 \\
\hline Servise yatış & 97 & 28.9 \\
\hline Yoğun bakıma yatış & 17 & 5.1 \\
\hline Acil serviste ölüm & 1 & 0.3 \\
\hline Toplam Mortalite & 4 & 1.2 \\
\hline
\end{tabular}

Karaciğer yaralanması olan 24 hastanın \%54 ünde aynı zamanda baş-boyun yaralanması, birinde toraks yaralanması vardı. Bu hastaların \%83'ü trafik kazası, \%8.3'ü yüksekten düşme, \%4.2'si delici- kesici alet yaralanması ile oluşmuştu. Bu olguların \%87.5'i erkek, \%12.5'u kadın idi. Bu hastaların \%20.8'ine $(\mathrm{n}=5)$ cerrahi tedavi, \%79.2'ine $(n=19)$ konservatif tedavi uyguladı. Bunların \%8.3'ü $(n=2)$ acil servisten taburcu 
Tablo 2: Solid Organ Yaralanması Olan Hastaların Özellikleri

\begin{tabular}{|c|c|c|}
\hline Cinsiyet & $\mathbf{n}$ & $\%$ \\
\hline Erkek & 37 & 86 \\
\hline Kadın & 6 & 14 \\
\hline \multicolumn{3}{|l|}{ Yaralanma Mekanizması } \\
\hline Araç içi trafik kazası & 36 & 83.7 \\
\hline Araç dışı trafik kazası & 2 & 4.7 \\
\hline Yüksekten düşme & 3 & 6.9 \\
\hline Delici kesici alet yaralanması & 2 & 4.7 \\
\hline \multicolumn{3}{|l|}{ Yaralanan Solid Organlar } \\
\hline Karaciğer & 24 & 55.8 \\
\hline Dalak & 18 & 41.9 \\
\hline Böbrek & 8 & 18.6 \\
\hline \multicolumn{3}{|l|}{ Fizik Muayene Bulguları } \\
\hline Karın ağrısı & 26 & 60 \\
\hline Hassasiyet & 24 & 56 \\
\hline Ekimoz & 15 & 34 \\
\hline Abrazyon & 9 & 22 \\
\hline Kesi & 2 & 4.7 \\
\hline Rebound & 8 & 18.6 \\
\hline Defans & 10 & 23.2 \\
\hline \multicolumn{3}{|l|}{ Acil Serviste Tedavi } \\
\hline Sıvı ve ilaç & 41 & 95.3 \\
\hline Kan ve kan ürünleri & 1 & 2.3 \\
\hline Mekanik ventilasyon & 1 & 2.3 \\
\hline \multicolumn{3}{|l|}{ Kesin Tedavi } \\
\hline Konservatif tedavi & 34 & 79.1 \\
\hline Cerrahi tedavi & 9 & 20.9 \\
\hline \multicolumn{3}{|l|}{ Sonuç } \\
\hline Acil servisten taburcu & 9 & 20.9 \\
\hline Servis yatış & 28 & 65.1 \\
\hline Yoğun bakım yatış & 6 & 14 \\
\hline Mortalite & 2 & 4.7 \\
\hline
\end{tabular}

edilmiştir, \%70.8'i $(n=17)$ servise, \%20.8'i $(n=5)$ yoğun bakım ünitesine yatırıldı. Bu hastaların GKS $14.29 \pm 1.39$ (10-15), ISS $16.25 \pm 10.96$ (1-41), NISS $17.54 \pm 11.78$ (1- 50), servis yatış günü $7.16 \pm 8.10$, yoğun bakım yatış günü $6.60 \pm 5.12$ idi. Karaciğer yaralanması olan hastalar içinde yoğun bakıma yatan 5 hastadan 2'si eks oldu. Ölüm görülen hastalardan
Tablo 3: Solid organların yaralanma derecelerinin dağılımı

\begin{tabular}{lll}
\hline $\begin{array}{l}\text { Karaciğer yaralanması } \\
\text { içinde }\end{array}$ & $\mathbf{n}$ & $\mathbf{\%}$ \\
\hline Grade 1 & 8 & 33.3 \\
Grade 2 & 10 & 41.7 \\
Grade 3 & 1 & 4.2 \\
Grade 4 & 4 & 16.7 \\
Grade 5 & 1 & 4.2 \\
\hline Dalak yaralanması içinde & & \\
\hline Grade 1 & 10 & 55.6 \\
Grade 2 & 6 & 33.3 \\
Grade 3 & 1 & 5.6 \\
Grade 4 & 1 & 5.6 \\
\hline Böbrek yaralanması içinde & & \\
\hline Grade 1 & 7 & 87.5 \\
Grade 2 & 1 & 12.5 \\
\hline
\end{tabular}

birinde karaciğer grade 1, diğerinde karaciğer grade 2 yaralanma mevcuttu. Her iki olguda kafa travması ve yaygın subaraknoid kanama vard1.

Dalak yaralanması olan olguların yaş ortalaması $39.66 \pm 17.13$ idi. Hastaların \%83.3'ü $(n=17)$ erkek, \%16.7'si (n=3) kadın idi. GKS 14.44 1.94 (12- 15), ISS $8.5 \pm 7.19$ (1- 25), NISS 9.66 \pm 18.22 (1- 29), servis yatış günü $5.16 \pm 4.59$, yoğun bakım yatış günü $9 \pm 2.8$ gün idi. Dalak yaralanması olan hastalardan 5'inde aynı zamanda karaciğer yaralanması, 2'sinde böbrek yaralanması mevcuttu.

Böbrek yaralanması olan olguların yaş ortalaması $35.25 \pm 12.53$ idi. Hastaların \%87.5'i $(n=7)$ erkek, $\% 12.5$ 'i (n=1) kadın idi. GKS 14.62 \pm 1.06 (12-15), ISS $3.00 \pm 4.17$ (1-13), NISS $4.25 \pm 7.30$ (1-22), servis yatış günü $1.12 \pm 0.35$ gün idi. Böbrek yaralanması olan hastalardan birinde aynı zamanda karaciğer yaralanması, ikisinde aynı zamanda dalak yaralanması mevcuttu.

Solid organ yaralanması olan hastaların ISS ve NISS değerleri diğer hastalardan anlamlı derecede yüksek bulundu ( $\mathrm{p}<0.05$, tablo 4 ). Hemoglobin ve hematokrit değerleri solid organ yaralanması olanlarda daha düşüktü. Üre ve kreatin değerlerinde solid organ yaralanması olan hastalarla diğer hastalar arasında fark bulunmaz iken AST ve ALT değerleri solid organ yaralanması olanlarda anlamlı yüksek tespit edildi $(\mathrm{p}<0.05$, tablo 4$)$. Karaciğer yaralanması olan olguların AST değeri ortalaması 184.25 \pm 183.18 iken ALT değeri $171.95 \pm 176.20$ idi. İzole böbrek ve dalak yaralanmaları olan olgularda ise AST ve ALT değerleri düşüktü. 
Phnx Med J. July, 2020. Volume 2 No 2

Tablo 4: Olguların Vital Bulguları, Laboratuar Değerleri ve Travma Skorlarının karşılaştırılması

\begin{tabular}{|c|c|c|c|c|}
\hline & $\begin{array}{l}\text { Tüm hastalar } \\
(\mathrm{n}=335)\end{array}$ & $\begin{array}{l}\text { Solid Organ Yaralanması } \\
\text { Yok } \\
(\mathrm{n}=292)\end{array}$ & $\begin{array}{l}\text { Solid Organ Yaralanması } \\
\text { Var } \\
(n=43)\end{array}$ & $\mathbf{p}$ \\
\hline & Ortalama $\pm S D$ & Ortalama \pm SD & Ortalama \pm SD & \\
\hline Sistolik kan basıncı & $115.2 \pm 6.4$ & $115.1 \pm 6.3$ & $115.7 \pm 7.1$ & 0.44 \\
\hline Diyastolik kan basıncı & $77.9 \pm 5.4$ & $73.1 \pm 5.1$ & $71.6 \pm 5.8$ & 0.09 \\
\hline Nabız & $87.6 \pm 4.4$ & $87.6 \pm 4.3$ & $88.3 \pm 5.2$ & 0.66 \\
\hline Solunum sayıs1 & $14.8 \pm 1.1$ & $14.9 \pm 1.1$ & $14.6 \pm 1.3$ & 0.03 \\
\hline Oksijen satürasyonu & $96.15 \pm 3.80$ & $95.9 \pm 6.6$ & $95.7 \pm 3.5$ & 0.04 \\
\hline GKS & $14.70 \pm 1.24$ & $14.7 \pm 1.5$ & $14.5 \pm 1.1$ & 0.02 \\
\hline ISS & $5.18 \pm 7.35$ & $4.2 \pm 6.2$ & $11.6 \pm 10.5$ & $<0.01$ \\
\hline NISS & $5.52 \pm 8.17$ & $4.4 \pm 6.7$ & $12.4 \pm 11.2$ & $<0.01$ \\
\hline Hct & $35.2 \pm 8.1$ & $35.9 \pm 8.0$ & $31.2 \pm 7.5$ & $<0.01$ \\
\hline $\mathrm{Hb}$ & $12.8 \pm 2.21$ & $13.0 \pm 2.7$ & $11.8 \pm 2.0$ & $<0.01$ \\
\hline Plt & $227.2 \pm 88.4$ & $231.7 \pm 90.6$ & $199.4 \pm 63.5$ & $<0.01$ \\
\hline WBC & $12.1 \pm 4.3$ & $12.1 \pm 4.4$ & $12 \pm 3.3$ & 0.83 \\
\hline Üre & $36.9 \pm 17.3$ & $36.6 \pm 16.6$ & $38.0 \pm 22.0$ & 0.73 \\
\hline Kreatin & $1.03 \pm 0.90$ & $1.1 \pm 0.3$ & $1.4 \pm 0.1$ & 0.17 \\
\hline ALT & $67.7 \pm 164.1$ & $56.6 \pm 159.8$ & $142.8 \pm 178.5$ & $<0.01$ \\
\hline AST & $71.1 \pm 105.9$ & $58.9 \pm 84.4$ & $153.2 \pm 180$ & $<0.01$ \\
\hline
\end{tabular}

Mann Whitney U testi, $p<0.05$ istatistiksel olarak anlamll

ISS $<16$ ile ISS $\geq 16$ olan iki grup karşılaştırıldığında; sistolik kan basınc1, diyastolik kan basıncı, oksijen saturasyonu, Hb, Hct, kan üre değeri, GKS ve servis yatış gün sayısı bakımından istatistiksel olarak anlamlılık vard1. NISS $<16$ ile NISS $\geq 16$ olan iki grup karşılaştırıldığında GKS, Hb, Hct, kan üre değeri, AST ve ALT ve servis yatış günü açısından anlamlı fark tespit edildi $(\mathrm{p}<0.05)$ (Tablo 5).

\section{TARTIŞMA}

Karın travmaları kafa ve ekstremite travmalarından sonra üçüncü sıklıkta görülür ve yaralanma en sık künt travma ile gerçekleşir (1-4). Bizim çalışmamızda da künt yaralanma penetran yaralanmadan sayıca daha fazla idi. Künt karın yaralanmalarının etyolojisinde trafik kazaları ilk sirayı almakta ve bunu sirasıyla düşmeler ve darp olayları izlemektedir (1-4). Penetran karın yaralanmalarında ise ateşli silah yaralanması ve delici kesici alet yaralanmaları ana nedenler olarak belirtilmektedir (1-4). Çalışmamızda etiyolojide ilk sırayı \%80.3 ile trafik kazaları oluştururken ikinci sırada \%4.8 delici kesici alet yaralamaları yer almaktayd1.

Çalışmamızda solid organ yaralanma oranı \%12.8 tespit edildi. Künt karın yaralanmalı olguların incelendiği çalışmalarda en sık yaralanan solid organın karaciğer olduğu ve bunu dalak ile böbrek yaralanmasının izlediği belirtilmiştir (5-7). Çalışmamızda solid organ yaralanması olan olgular kendi içinde değerlendirildiğinde literatürle uyumlu olarak ilk sirada \%55.8 oranla karaciğer yaralanması yer alırken onu \%41.9 ile dalak yaralanması izledi. Böbrek yaralanmasının oranı ise \%18.6 olarak tespit edildi. Penetran karın yaralanmasında delici kesi aletlerle olan yaralanmalar ateşli silah yaralanmalarına göre neredeyse üç kat daha sık görülmesine rağmen içerdikleri düşük enerjiden dolayı bu yaralanmaların mortalite ve morbiditesi daha azdır $(8,9)$. Penetran karın travmalarında intestinal organların yaralanma sıklığı solid organlara oranla daha sıktır. Literatürde en sık yaralanan solid organın dalak olduğu belirtilmekte bunu sirasiyla karaciğer ve dalak izlemektedir $(8,10)$. Bizim çalışmamızda sadece iki olguda penetran yaralanmaya bağlı olarak karaciğer yaralanması mevcuttu. Diğer solid organ yaralanmalarının hepsi künt travmaya bağlı oluşmuştu. Penetran yaralanmalara bağlı ise intestinal organ perforasyonu daha sık görüldü. 
Tablo 5: Tüm olguların yaralanma şiddet skorlarına göre vital bulguları, laboratuar değerleri ve hastanede kalış sürelerinin karşılaştırılması

\begin{tabular}{|c|c|c|c|}
\hline & & ISS $<16$ & $\mathbf{p}$ \\
\hline & Ortalama \pm SD & Ortalama \pm SD & \\
\hline Yaş & $42.51 \pm 19.42$ & $41.47 \pm 18.28$ & $>0.05$ \\
\hline Sistolik Tansiyon & $112.2 \pm 6.9$ & $115.79 \pm 6.18$ & $<0.05$ \\
\hline Diyastolik tansiyon & $70.7 \pm 5,6$ & $73.35 \pm 4.99$ & $<0.05$ \\
\hline Solunum say1s1 & $14.3 \pm 1.94$ & $14.99 \pm 0.93$ & $>0.05$ \\
\hline Nabız & $88.5 \pm 4.10$ & $87.48 \pm 4.46$ & $>0.05$ \\
\hline Saturasyon & $94.87 \pm 4.57$ & $96.09 \pm 6.56$ & $<0.05$ \\
\hline GKS & $13.70 \pm 2.22$ & $14.89 \pm 0.82$ & $<0.05$ \\
\hline NISS & $21.57 \pm 7.48$ & $2.45 \pm 3.17$ & $<0.05$ \\
\hline Hct & $30.21 \pm 8.18$ & $36.22 \pm 7.81$ & $<0.05$ \\
\hline $\mathrm{Hb}$ & $12.07 \pm 2.12$ & $13.06 \pm 2.72$ & $<0.05$ \\
\hline WBC & $12.87 \pm 5.56$ & $11.98 \pm 4.04$ & $>0.05$ \\
\hline PLT & $235.88 \pm 147.84$ & $225.60 \pm 71.96$ & $>0.05$ \\
\hline Üre & $42.01 \pm 20.41$ & $35.92 \pm 16.59$ & $<0.05$ \\
\hline Kreatin & $1.28 \pm 1.93$ & $3.45 \pm 19.88$ & $>0.05$ \\
\hline ALT & $114.57 \pm 177.77$ & $58.76 \pm 160.17$ & $>0.05$ \\
\hline AST & $112.20 \pm 153.89$ & $63.32 \pm 92.35$ & $>0.05$ \\
\hline \multirow[t]{2}{*}{ Servis yatış günü } & $17.19 \pm 28.59$ & $1.50 \pm 6.16$ & $<0.05$ \\
\hline & NISS $\geq 16$ & NISS $<16$ & $\mathbf{P}$ \\
\hline Yaş & $42.27 \pm 19.32$ & $41.52 \pm 18.30$ & $>0.05$ \\
\hline Sistolik Tansiyon & $112.00 \pm 7.044$ & $115.85 \pm 6.11$ & $>0.05$ \\
\hline Diyastolik tansiyon & $70.63 \pm 5.69$ & $73.38 \pm 4.98$ & $>0.05$ \\
\hline Solunum sayıs1 & $14.29 \pm 1.95$ & $15.00 \pm 0.92$ & $>0.05$ \\
\hline Nabiz & $88.76 \pm 4.25$ & $87.44 \pm 4.43$ & $>0.05$ \\
\hline Saturasyon & $94.78 \pm 4.58$ & $96.11 \pm 6.56$ & $>0.05$ \\
\hline GKS & $13.67 \pm 2.21$ & $14.85 \pm 1.20$ & $<0.05$ \\
\hline ISS & $19.94 \pm 5.60$ & $41.52 \pm 18.30$ & $>0.05$ \\
\hline Hct & $30.32 \pm 8.14$ & $36.22 \pm 7.83$ & $<0.05$ \\
\hline $\mathrm{Hb}$ & $12.05 \pm 2.11$ & $13.07 \pm 2.72$ & $<0.05$ \\
\hline WBC & $12.94 \pm 5.53$ & $11.97 \pm 4.04$ & $>0.05$ \\
\hline PLT & $235 \pm 146.60$ & $225.74 \pm 72.05$ & $>0.05$ \\
\hline Üre & $41.83 \pm 20.27$ & $35.93 \pm 16.62$ & $<0.05$ \\
\hline Kreatin & $1.28 \pm 1.91$ & $3.45 \pm 19.92$ & $>0.05$ \\
\hline ALT & $119.41 \pm 179.7$ & $57.62 \pm 159.29$ & $<0.05$ \\
\hline AST & $117.50 \pm 157.46$ & $62.11 \pm 90.24$ & $<0.05$ \\
\hline Servis yatış günü & $14.01 \pm 23.98$ & $1.50 \pm 6.17$ & $<0.05$ \\
\hline
\end{tabular}

Literatürde karın yaralanmaları ile ilgili olarak yapılan çalışmalarda erkeklerin kadınlara göre daha yüksek oranda travmaya maruz kaldığ 1 bildirilmektedir. Batıda ve ABD'de travma olgularında kadın erkek oranı birbirine yakınken ülkemizdeki serilerde olguların büyük kısmının erkek olduğu görülmektedir (11-15). Biz de bu çalışmada erkeklerin kadınlara göre daha fazla oranda karın travmasına maruz kaldıklarını tespit ettik. Karın travmasına maruz kalan erkek sayısının kadınlara göre daha yüksek oranda olmasının nedeni 


\section{Phnx Med J. July, 2020. Volume 2 No 2}

olarak kadın cinsiyetin iş ve sosyal yaşama katılımın daha sınırlı olmasından kaynaklanabileceğini düşünmekteyiz.

Fizik muayene, günümüzde acil laparatomi endikasyonu koyulması açısından hala en önemli araçlarımızdan biridir. Kafa travması, madde alımı ve nörolojik bir hastalığa bağlı gelişen nörolojik işlev bozukluğu olmayan hastaların fizik muayenesinde ağrı, hassasiyet, rebaund ve defans gibi bulguların olması karın içi organ yaralanmasını gösterebilir (4). Bizim çalışmamızda tüm hastaların \%74.4'ünde karın ağrısı, \%68.4'ünde hassasiyet mevcuttu. Davis ve ark. (16) çalışmalarında karın travmalı olguların en sık karın ağrısı yakınması ile hastaneye başvurduklarını ve bu hastaların muayenelerinde $\% 75$ oranında karında hassasiyet ve defans, \%28 oranında ise rebaund bulduklarını belirtmişlerdir. Solid organ yaralanması tespit edilen hastalarımızın fizik muayenelerine bakıldığında ise hastaların \%60'ında karın ağrısı, $\% 56$ 'sinda hassasiyet, \%19'unda rebaund vard1. Bu oranlar literatürle uyumlu idi. Çoklu travma hastalarında diğer sistem yaralanmaları göz önünde bulundurulduğunda karın fizik muayene bulguları yanıltıcı olabilmektedir.

Hemoglobin ve hematokrit değerlerindeki düşmeler karın içi kanamanın bir göstergesi olabilir (77). Bizim çalışmamızda da hem solid organ yaralanması olan hastaların hem de travma skorları yüksek olan hastaların hemoglobin ve hematokrit değerleri diğer hastalara kıyasla düşük bulundu.

Rutin biyokimyasal incelemede; transaminazlarda artış bulunması karaciğer yaralanmasını ve kreatin düzeyindeki artışlar böbrek yaralanmasını gösterebilmesi açısından karın travmalı hastaları değerlendirmede bize yardımcı olabilen parametrelerdir (15). Solid organ yaralanması olan hastalarımızın transaminaz değerleri literatürle uyumlu olarak anlamlı yüksekti. Künt karaciğer yaralanmasında serum AST düzeyinin $100 \mathrm{IU} / \mathrm{L}$ ve ALT düzeyinin $80 \mathrm{IU} / \mathrm{L}$ üzerinde olmasının karaciğer yaralanmasını ve şiddetini gösterebilmektedir (15). ALT $\leq 76 \quad \mathrm{u} / \mathrm{l}$, AST $\leq 130 \quad \mathrm{u} / \mathrm{l} \quad$ ve laktat dehidrogenez $\leq 410$ olan karaciğer hasarı olan hastalar konservatif olarak izlenebilir (17). Bizim çalışmamızda özellikle karaciğer yaralanması olan olguların AST değeri ortalaması $184.25 \pm 183.18$ iken ALT değeri $171.95 \pm 176.20$ idi. İzole böbrek ve dalak yaralanmaları olan olgularda ise AST ve ALT değerleri düşüktü.

Günümüzde hemodinamik olarak stabil künt karın yaralanması olan hastalarda yüksek operatif komplikasyonlardan dolayı konservatif tedavi cerrahi tedavinin yerini almıştır. Özellikle son yıllarda bilgisayarlı tomografinin kullanıma girmesi, travma merkezlerinin oluşturulması, labaratuar ve yoğun bakım hizmetlerinin gelişmesi konservatif izlem sürecine katkı sağlamıştır (18). Hemodinamik olarak stabil olmayan veya takibinde peritonit bulguları gelişen künt karın travması olan hastalar cerrahi olarak tedavi edilmektedir $(8,15)$. Künt karın yaralanması ile karşılaştırıldığında penetran karın yaralanmalarında cerrahi tedavi konservatif tedaviye göre daha sik uygulanmaktadır $(4,8,15)$. Bizim çalışmamızda da bu verilerle uyumlu olarak künt travmaya bağlı solid organ yaralanması olan hastaların çoğunluğu (\%79.1) konservatif olarak tedavi edilmiştir.

İster penetran ister künt mekanizma ile meydana gelsin karın yaralanmalı bir hastada hipovolemik şok ve içi boş organ yaralanmasına bağlı gelişen peritonit, septik şok ve multi organ yetmezliği nedenlerinden ötürü ölüm gelişebilir $(1,2,3,4,15)$. Karın içi solid organlarda yaralanma tespit ettiğimiz hastaların hiçbirinde karın içindeki yaralanmaya bağlı ölüm tespit etmedik. Literatürde karın yaralanması olan hastaların mortalite oranları \%12.6 ile \%21.3 arasında olduğu görülmektedir $(12,19,20)$. Künt karın yaralanmaları penetran yaralanmalara oranla daha yüksek bir mortalite oranına sahiptir $(4,15)$. Travmaya bağlı ölümler yaşla birlikte artmakta olup 55 yaş üzeri hastalarda mortalite oranı 55 yaş altı hastalara göre yaklaşık 2 kat daha fazladır (21). Azalmış işlevsel rezervlerinden dolayı geriatrik hastalar yaralanmaların olumsuz sonuçlarından daha çok etkilenmektedir (22). Finelli ve ark. (23) travma olgularında yaşın sağ kalım üzerine etkisini değerlendirdikleri bir çalışmada 65 yaş ve üzeri grupta ölüm oranını genç popülasyona göre \%89 daha fazla olarak saptamışlardır. Çalışmamızda künt karın travmasına bağlı solid organ yaralanması olan olguların mortalite oranı \%4.7 idi. Ancak bu olgularda ölüm karın yaralanmasına eşlik eden ağır kafa travmalarına bağlı idi. Ölüm oranımızın düşük çıkması; hasta sayımızın az olmasına, hastalarımızın yaş ortalamasının düşük olmasına, bilgisayarlı tomografi gibi gelişmiş tetkik araçları ile erken dönemde organ yaralanması ve yaralanma derecesinin tespit edilmesine ve zaman kaybetmeden hastanın uygun tedavi edilmesine bağlanabilir.

Mortalite ve morbiditeyi etkileyen diğer faktörler arasında karın travması sonrasında hastane ya da travma merkezine ulaşmada geçen süre, bu merkezlerde tedavide gecikme, kronik hastalık varlığ 1 , iki ya da fazla intra abdominal organda yaralanma, eşlik eden ikiden fazla karın dışı bölgede yaralanma, etkilenen organın yaralanma derecesi, yüksek travma indeksi, kan replasmanı ihtiyac1, multi organ yetmezliği, şok varlığı sayılabilir (24-26). Ciddi karın travması olan olgulara siklıkla ortopedik, torasik ve santral sinir sistemi yaralanması eşlik etmektedir (27). Gad ve arkadaşlarının yaptıkları çalışmada karın travması tespit edilen olgulara sirasıyla ekstremite, toraks ve baş-boyun yaralanması eşlik ettiğini belirtmişlerdir (28). Bizim çalışmamızda karın yaralanmasına eşlik eden diğer sistemlere bakıldığında ilk sırada baş-boyun yaralanmaları yer almıştır. Travma skorları yüksek olan, yoğun bakıma yatan ve mortal seyreden olgularımızda da kafa travması ilk sirada bulunmaktadır.

Sonuç olarak; karın yaralanma olgularında birden fazla karın içi organ yaralanması, eşlik eden karın dışı 


\section{Acar et al}

yaralanmalar, etkilenen solid organın yaralanma derecesi, yüksek travma indeksi mortalite ve morbiditeyi etkileyen faktörler arasında yer almaktadır.

Çıkar İlişkisi

Tüm yazarlar çıkar çatışması olmadığını beyan eder.

\section{KAYNAKLAR}

1. French LK, Gordy S, O. John Ma. Abdominal Trauma. In Tintinalli JE, Stapczynski JS, Ma OJ, Yealy DM, Meckler GD, Cline DM (eds): Emergency Medicine A Comprehensive Study Guide. 8th ed. New York: The Mac Graw Hill Companies, 2015.

2. Isenhour JL, Marx J. Advances in Abdominal Trauma. Emerg Med Clin N Am 2007;25:713-733.

3. Poletti PA, Mirvis SE, Shanmuganathan K, Takada T, Killeen KL, et al. Blunt abdominal trauma patients: can organ injury be excluded without performing computed tomography? J Trauma. 2004;57:1072-81.

4. Ozkan S. Karın Yaralanmaları. Tüm Yönleriyle Acil Tıp: Tanı, Tedavi ve Uygulama Kitabı. Ed: Zeynep Kekeç. 3. Baskı, Akademisyen Tip Kitabevi, 2013, s:859-866.

5. Salimi J, Ghodsi M, Zavvarh MN, Khaji A. Hospital management of abdominal trauma in Tehran, Iran: a review of 228 patients. Chin J Traumatol. 2009;12:259-62.

6. Demetriades D, Hadjizacharia P, Constantinou C, Brown C, Inaba K, Rhee P, et al. Selective non operative management of penetrating abdominal solid organ injuries. Ann Surg. 2006;244:620-8.

7. Yanar H, Ertekin C, Taviloglu K, Kabay B, Bakkaloglu H, Guloglu R. Nonoperative treatment of multipleintra-abdominal solid organ injury after blunt abdominal trauma. The Journal of Trauma 2008;4:943-8.

8. Isenhour JL, Marx J. Advances in abdominal trauma. Emerg Med Clin North Am. 2007;25:713-33.

9. Butt MU, Zacharias N, Velmahos GC. Penetrating abdominal injuries: management controversies. Scand J Trauma Resusc Emerg Med. 2009;17:17-19.

10. Dodiyi-Manuel A, Jebbin NJ, Igwe PO. Abdominal injuries in university of port harcourt teaching hospital. Niger J Surg 2015;21:18-20.

11. Boullion B, Lefering R, Vorveg M, Tiling T, Neugebauer E, Troidl H. Travma score systems: Colognevalidationstudy. J Travma. 1997; 42:652-658.

12. Girgin S, Gedik E, Tacyılmaz İH. Kunt karaciğer travmasında uyguladığımız cerrahi yontemlerin değerlendirilmesi. Ulus Travma Acil Cerrahi Derg. 2006; 12: 35-42.

13. Karamercan A, Yilmaz TU, Karamercan MA, Aytac B. Blunt abdominal trauma: evaluation of diagnostic options and surgical outcomes. Ulus Travma Acil Cerrahi Derg. 2008; 14: 205-10.

14. Taviloğlu K, Günay K, Şahin A, Ertekin C, Türel Ö. Gastrointestinal sistem travmalarına yaklaşım. Ulus. Travma Derg. 1995; 2:126-134.

15. Guloğlu R, Yanar H. Karın yaralanmaları. Travma Ed: Ertekin C, Taviloğlu K, Guloğlu R, Kurtoğlu M. Birinci baskı, İstanbul; İstanbul Medikal Yayıncılık; 2005. p. 875-85.

16. Davis JJ, Cohn I, Nance FC. Diagnosis and management of blunt abdominal trauma. Ann Surg $1998 ; 183$ :672.

17. Bilgic I, Gelecek S, Akgun AE, Ozmen MM. Predictive value of liver transaminases levels in abdominal trauma. Am J Emerg Med. 2014;32:705-8.

18. Raza M, Abbas Y, Devi V, Prasad KV, Rizk KN, Nair PP. Non operative management of abdominal trauma-a 10 years review. World J Emerg Surg. 2013;8:14.

19. Koksal O, Ozdemir F, Bulut M, Aydin S, Almacioğlu ML, Ozguc H. Comparison of trauma scoring systems for predicting mortalty in firearm injuries. Ulus Travma Acil Cerrahi Derg. 2009; 15: 559-64.

20. Duzgun AP, Ozmen MM, Salyam B, Coșkun F. Factors influencing mortality in traumatic ruptures of diaphragm. Ulus Travma Acil Cerrahi Derg 2008;14: 132-8.

21. Copes WS, Champion HR, Sacco WJ, Lawnick MM, Keast SL, Bain LW. The injury severity scorere visited. J Trauma 1988; 28:69-77.

22. Joseph B, Zangbar B, Pandit V, Kulvatunyou N, Haider A, O'Keeffe T, et al. Mortality after trauma laparotomy in geriatric patients. J SurgRes. 2014;190:662-6.

23. Finelli FC, Jonsson J, Champion HR, Morelli S, Fouty WJ. A case control study for major trauma in geriatric patients. J Trauma. 1989; 31:1216-26.

24. Gad MA, Saber A, Farrag S, Shams ME, Ellabban GM. Incidence, Patterns, and Factors Predicting Mortality of Abdominal Injuries in Trauma Patients. N Am J Med Sci. 2012;4:129-134.

25. Nahm NJ, Como JJ, Vallier HA.The impact of majör operative fractures in blunt abdominal injury. J Trauma Acute Care Surg 2013;74:1307-14.

26. Iflazoglu N, Ureyen O, Oner OZ, Tusat M, Akcal MA. Complications and risk factors for mortality in penetrating abdominal firearm injuries: analysis of 120 cases. Int J Clin Exp Med. 2015;8:6154-62.

27. Costa G, Tierno SM, Tomassini F, Venturini L, Frezza B, Cancrini G, Stella F. The epidemiology and clinical evaluation of abdominal trauma. An analysis of a multi disciplinary trauma registry. Ann Ital Chir. 2010;81:95-102.

28. Gad MA, Saber A, Farrag S, Shams ME, Ellabban GM. Incidence, patterns, and factors predicting mortality of abdominal injuries in trauma patients. N Am J Med Sci. 2012;4:129-34 